\title{
Radical oxygen species production induced by advanced oxidation protein products predicts clinical evolution and response to treatment in systemic sclerosis
}

\author{
A Servettaz, P Guilpain, C Goulvestre, C Chéreau, C Hercend, C Nicco, L Guillevin, B Weill, \\ L Mouthon, F Batteux
}

Ann Rheum Dis 2007;66:1202-1209. doi: 10.1136/ard.2006.067504

See end of article for authors' affiliations

Correspondence to: Frédéric Batteux, Laboratoire $\mathrm{d}^{\prime}$ Immunologie, Pavillon Hardy, Hôpital Cochin, 75679 Paris cedex 14 France; frederic.batteux@ cch.ap-hop-paris.fr

Accepted 9 March 2007 Published Online First 15 March 2007 ve oxygen species (ROS) in the development of the various patterns Objectives: To investigate the role of reactive oxygen species (ROS) in the development of the various patter
of systemic sclerosis (SSc) and the mechanisms of ROS production by endothelial cells and fibroblasts. Methods: Production of hydrogen peroxide $\left(\mathrm{H}_{2} \mathrm{O}_{2}\right)$, nitric oxide $(\mathrm{NO})$ and cellular proliferation were determined following incubation of endothelial cells and fibroblasts with 56 SSc and 30 healthy sera. Correlations were established between those markers, the type and the severity of the clinical involvements, and the response to treatment. The factors leading to ROS production were determined.

Results: $\mathrm{H}_{2} \mathrm{O}_{2}$ production by endothelial cells and fibroblasts was higher after incubation with SSc sera than with normal sera $(p<0.001)$ and with sera from SSc patients with severe complications than sera from other patients $(p<0.05)$. Sera from patients with lung fibrosis triggered the proliferation of fibroblasts more than other SSc sera $(p<0.001)$, whereas sera from patients with vascular complications exerted no proliferative effect on fibroblasts, but inhibited endothelial cell growth $(p<0.05)$ and induced $N O$ overproduction $(p<0.05)$. Bosentan reduced NO release by $32 \%$, whereas $\mathrm{N}$-acetylcystein potentiated 5 -fluorouracil $(5 \mathrm{FU})$ to inhibit fibroblast proliferation by $78 \%$. Those serum-mediated effects did not involve antibodies but advanced oxidation protein products that selectively triggered cells to produce $\mathrm{H}_{2} \mathrm{O}_{2}$ or $\mathrm{NO}$.

Conclusions: SSc sera induce the production of different types of ROS that selectively activate endothelial cells or fibroblasts, leading to vascular or fibrotic complications. Assaying serum-induced ROS production allows clinical activity of the disease to be followed and appropriate treatments to be selected.
$\mathrm{S}$ ystemic sclerosis (SSc) is a connective tissue disorder of unknown aetiology; the main features are vascular hyperreactivity and fibrosis of skin and visceral organs. ${ }^{12}$

SSc is characterized by a large variety of clinical patterns. Although genetic and environmental factors are known to play a role in the initiation and progression of the disease, the mechanisms that determine the clinical manifestations remain unclear. $^{3-5}$

Recent reports have suggested that oxidative stress could be involved in the pathogenesis of $\mathrm{SSc}^{6-9}$ and spontaneous production of reactive oxygen species (ROS) by skin fibroblasts from SSc patients has been observed. ${ }^{6}{ }^{10}$

Our aim was to determine whether serum factors can mediate an oxidative stress that activates endothelial cells and fibroblasts in SSc patients. The involved ROS and their respective effects on both types of cell have been characterized in order to determine the mechanisms that lead to a vascular or a fibrotic form of the disease. In addition, various drugs and antioxidant molecules have been tested for their counteracting effects on the oxidative stress.

\section{PATIENTS AND METHODS}

\section{Patients and sera}

Fifty-six SSc patients were enrolled in the study. The clinical and serological characteristics of these SSc patients are summarized in table 1 .

The onset of the disease was defined as the time of the first non-Raynaud's phenomenon. To be eligible for the study, patients had to fulfill the American College of Rheumatology criteria and/or the Leroy \& Medsger criteria for SSc. ${ }^{11-13}$ Limited cutaneous SSc was defined by skin thickening in areas solely distal to the elbows and knees, and diffuse cutaneous SSc was defined by the presence of skin thickening that was proximal, as well as distal, to the elbows and knees. ${ }^{12}$

Interstitial lung disease was assessed by chest high-resolution computed tomodensitometry and pulmonary function test values. A restrictive syndrome (RS) was defined by a reduction $(<75 \%)$, compared with values obtained from a well-defined population of normal subjects, matched for gender, age, height and ethnic origin using similar test protocols in both forced expired volume in one second $\left(\mathrm{FEV}_{1}\right)$ and forced vital capacity ( $\mathrm{FVC}$ ), and $\mathrm{FEV}_{1} / \mathrm{FVC}$ ratio $>75 \%$.

Vascular abnormalities (VAs) were defined as digital ulcers or scars of ulcers related to digital ischaemia or pulmonary arterial hypertension (PAH) defined by systolic pulmonary arterial pressure $>40 \mathrm{mmHg}$ following echocardiography and/ or mean pulmonary arterial pressure $>25 \mathrm{mmHg}$ following right-heart catheterization in the absence of RS. Twelve patients presenting with active digital ulcers, and/or scars of digital ulcers, and six patients with PAH in the absence of RS, were classified as patients with VAs. One patient had both digital ischaemia and $\mathrm{PAH}$, and this was taken into account in both groups. The eight patients with $\mathrm{PAH}$ associated with a RS were not included in the group of patients with vascular primitive PAH in order to form a homogenous group of patients with primitive vascular abnormalities. Only 1 of 56 patients had

Abbreviations: AOPPs, advanced oxidation protein products; DAF2-DA, 4,5-diaminofluorescein diacetate; 5FU, 5-fluorouracil; H2-DCFDA, 2' , 7' dichlorodihydrofluorescein diacetate; $\mathrm{HCs}$, healthy controls; HUVECs, human umbilical venous endothelial cells; NAC, N-acetyl-L-cysteine; NO, nitric oxide; $\mathrm{PAH}$, pulmonary arterial hypertension; $\mathrm{ROS}$, reactive oxygen species; RS, restrictive syndrome; SSc, systemic sclerosis; VAs, vascular abnormalities 
Table 1 Clinical and serological characteristics of the 56 SSc patients

\begin{tabular}{lc}
\hline & SSc Patients \\
\hline Age, years & $53 \pm 15.9$ \\
Duration of SSc, years & $8 \pm 7.4$ \\
Duration of Raynaud syndrome, years & $14 \pm 14$ \\
Female sex, $\mathrm{n}(\%)$ & $47(83.9)$ \\
Diffuse SSc, $\mathrm{n}(\%)$ & $39(69.6)$ \\
RS, $\mathrm{n}(\%)$ & $11(19.6)$ \\
Digital ischaemia, $\mathrm{n}(\%)$ & $12(21)$ \\
Renal crisis, $\mathrm{n}(\%)$ & $6(10.7)$ \\
Total PAH, $\mathrm{n}(\%)$ & $14(25)$ \\
PAH associated with RS, $\mathrm{n}(\%)$ & $8(14.3)$ \\
PAH not associated with RS, $\mathrm{n}(\%)$ & $6(10.7)$ \\
Specific autoantibodies, $\mathrm{n}(\%)$ & $15(26.8)$ \\
Anti-centromere antibodies, $\mathrm{n}(\%)$ & $8(14.3)$ \\
Anti-DNA topoisomerase I antibodies, $\mathrm{n}(\%)$ & $7(12.5)$ \\
Immunosuppressant at the time of serum collection collection, & $7(12.5)$ \\
$\mathrm{n}(\%)$ & $7(12.5)$ \\
ACE inhibitors at the time of serum collection, $\mathrm{n}(\%)$ & $7 \%$ \\
\hline
\end{tabular}

$\mathrm{ACE}$, angiotensin-converting enzyme; $\mathrm{PAH}$, pulmonary arterial hypertension; RS, restrictive syndrome; SSc, systemic sclerosis. Plus-minus values are Means + SEM.

No difference was observed between these groups of patients by one-way ANOVA and multivariate analysis in terms of age, duration of disease or duration of Raynaud's phenomenon.

both RS and VAs, and this was taken into account in both groups.

As no sample contemporary of a renal crisis was available, this complication was not used to classify patients in this study. Two patients had tendon friction rubs. None of the 56 patients had another connective tissue disease or cancer.

Normal sera were collected from 30 healthy adults (22 females and 8 males, mean age $44 \pm 17$ years). All patients and controls gave their written informed consent.

\section{Cells and chemicals}

Human umbilical venous endothelial cells (HUVECs) were obtained by digestion of umbilical cords with $0.1 \%$ collagenase. NIH 3 T3 fibroblasts were obtained from the American Type Culture Collection (Manassas, VA). HEp-2 cells were obtained from EuroBio (Les Ulis, France). Primary normal human dermal fibroblasts were a gift from A. Munnich (INSERM 781, Necker Hospital, Paris, France). All cells were cultured as previously reported. ${ }^{14} 15$

\section{Measurement of hydrogen peroxide and nitric oxide production}

Cells $\left(8 \times 10^{3}\right.$ per well) were seeded in 96-well plates (Costar, Corning, Inc, NY) and incubated with their respective growth medium alone for 12 hours at $37^{\circ} \mathrm{C}$ in $5 \% \mathrm{CO}_{2}$. Culture media were then removed and cells pre-incubated with $50 \mu \mathrm{l} 2^{\prime}, 7^{\prime}$ dichlorodihydrofluorescein diacetate (H2-DCFDA) diluted 1:1000 in phosphate-buffered saline (PBS) to test cellular hydrogen peroxide $\left(\mathrm{H}_{2} \mathrm{O}_{2}\right)$ production or with $50 \mu \mathrm{l} 4,5$ diaminofluorescein diacetate (DAF2-DA) diluted 1:375 in PBS to test nitric oxide (NO) release. After 30 minutes, $50 \mu \mathrm{l}$ of SSc or control sera were added, and $\mathrm{H}_{2} \mathrm{O}_{2}$ and NO productions were assayed spectrofluorimetrically after 6 hours (Fusion, PerkinElmer, Wellesley, MA, USA). Results were expressed in arbitrary units (AUs) per minute and per million cells.

\section{In vitro cell proliferation assays}

HUVECs, as well as NIH 3T3, human primary fibroblasts or HEp-2 cells $\left(4 \times 10^{3}\right.$ per well $)$, were seeded in 96-well plates (Costar) and incubated with $50 \mu \mathrm{l}$ of SSc or control serum and $150 \mu \mathrm{l}$ of culture medium without fetal bovine serum (FBS) at $37^{\circ} \mathrm{C}$ in $5 \% \mathrm{CO}_{2}$ for 48 hours. Cell proliferation was determined by pulsing the cells with $\left[{ }^{3} \mathrm{H}\right]$ thymidine $(1 \mu \mathrm{Ci} /$ well $)$ during the last 16 hours of culture. Results were expressed as absolute numbers of counts per minute.

\section{Assay of serum anti-endothelial and anti-fibroblast antibodies}

NIH 3T3 fibroblasts and HUVECs $\left(4 \times 10^{4}\right.$ cells per well $)$ were incubated with 1:5 dilution of SSc or control sera for 1 hour at $4^{\circ} \mathrm{C}$, then washed in PBS and incubated with 1:200 FITC-rabbit polyclonal anti-human IgG, A, M antibody (Dako, Glostrup, Denmark) for 1 hour at $4^{\circ} \mathrm{C}$. Fluorescence intensity was determined spectrofluorometrically and expressed as AUs.

\section{Assay of advanced oxidation protein products in sera}

Advanced oxidation protein products (AOPPs) were measured by spectrophotometry as previously described.$^{16}$ The assay was calibrated using chloramine-T. The absorbance was read at $340 \mathrm{~nm}$ on a microplate reader (Fusion, PerkinElmer, Wellesley, MA, USA). AOPP concentrations were expressed as $\mu \mathrm{mol} / \mathrm{l}$ of chloramine-T equivalents.

\section{ROS production by cellular AOPP}

HUVEC protein extracts were obtained by incubation of HUVECs with 1\% NP40 and protease inhibitors in PBS buffer. Proteins were oxidized by $1 \mathrm{mM} \mathrm{HOCl}$ for 1 hour or $1 \mathrm{mM}$ peroxynitrites for 18 hours at room temperature, then dialysed overnight against PBS and tested for AOPP content. Endothelial cells and NIH 3T3 cells $\left(8 \times 10^{3}\right.$ per well $)$ were incubated with $0.5 \mathrm{mg}$ per well of either unoxidized or oxidized HUVEC extracts. Production of $\mathrm{H}_{2} \mathrm{O}_{2}$ and $\mathrm{NO}$ was assessed spectrofluorometrically using H2-DCFDA and DAF2-DA as described above.

\section{Effects of drugs on serum-induced ROS production}

SSc sera were incubated with either $50 \mu \mathrm{M}$ bosentan (Actelion, Allschwil, Switzerland), $10 \mu \mathrm{M}$ nifedipine (Bayer Pharma, Leverkusen, Germany), $50 \mu \mathrm{M}$ D-penicillamine (Dexo, Saint Cloud, France) or $10 \mu \mathrm{g}$ etanercept (Wyeth, Madison, USA) in PBS for 90 minutes at $37^{\circ} \mathrm{C}$. PBS alone was used as control. HUVECs $\left(8 \times 10^{3}\right.$ per well $)$, seeded in 96 -well plates, were incubated with $50 \mu \mathrm{l}$ of H2-DCFDA or DAF2-DA. After 30 minutes, the sera with drugs were added, and $\mathrm{H}_{2} \mathrm{O}_{2}$ and NO productions were assessed as above. In other experiments, HUVECs and NIH 3T3 cells $\left(8 \times 10^{3}\right.$ per well $)$ were incubated with $1600 \mu \mathrm{M} \mathrm{N}$-acetyl-L-cysteine (NAC), $400 \mu \mathrm{M}$ reduced glutathione (GSH) or $10 \mathrm{U}$ PEG-catalase for 18 hours at $37^{\circ} \mathrm{C}$ in $5 \% \mathrm{CO}_{2}$. Medium and chemicals were removed and replaced by $50 \mu \mathrm{l}$ of H2-DCFDA (for HUVECs and NIH 3T3 cells) or DAF2-DA (for HUVECs). After 30 minutes, $50 \mu \mathrm{l}$ serum diluted 1:2 were added and ROS production was assessed as above. Results were expressed as percentages of ROS production versus untreated cells $(100 \%)$.

\section{Effects of drugs on serum-induced HUVECs and fibroblast proliferation}

NIH 3T3 cells or HUVECs $\left(4 \times 10^{3}\right.$ per well $)$ were incubated with SSc or control serum ( $1: 8 \mathrm{v}: \mathrm{v})$ in culture medium without FBS at $37^{\circ} \mathrm{C}$ in $5 \% \mathrm{CO}_{2}$ for 48 hours. For NIH $3 \mathrm{T3}$ cells, one of the following molecules was added: $1600 \mu \mathrm{M} \mathrm{NAC}, 400 \mu \mathrm{M}$ reduced GSH, $10 \mu \mathrm{M}$ nifedipine, $50 \mu \mathrm{M}$ D-penicillamine, $50 \mu \mathrm{M}$ bosentan, $10 \mu \mathrm{g}$ etanercept, $10 \mathrm{U}$ PEG-catalase or $25 \mu \mathrm{M}$ 5FU (Dakota Pharm, Le Plessis Robinson, France), with or without $1600 \mu \mathrm{M}$ NAC. For HUVECs, $600 \mu \mathrm{M}$ NAC, $400 \mu \mathrm{M}$ reduced GSH or 10 U PEG-catalase were added. Cell proliferation was assessed as described above. Results were expressed as percentages of cellular proliferation versus untreated cells $(100 \%)$. 
Longitudinal study of in vitro ROS production by HUVECs and of NIH 3T3 fibroblast proliferation

A longitudinal study was performed with the sera from 5 patients. Productions of $\mathrm{H}_{2} \mathrm{O}_{2}$ and $\mathrm{NO}$, cell proliferation and serum AOPP concentration were measured as previously described.

\section{Statistical analysis}

Data were compared with the Student's $t$ unpaired, paired tests and Fisher's exact test. When analysis included $>2$ groups, one-way ANOVA was used. Pearson's r correlation coefficient was used to analyse the relationships between quantitative variables. A p value $<0.05$ was considered to be significant. Quantitative values higher than 2 SD above the mean obtained with control sera were considered to be positive.

\section{RESULTS}

Effects of SSc sera on ROS production and proliferation of fibroblasts, HUVECs and HEp-2 cells

HUVECs, NIH 3 T3 fibroblasts or HEp-2 cells exposed to SSc sera released higher amounts of $\mathrm{H}_{2} \mathrm{O}_{2}$ than when exposed to normal sera ( $\mathrm{p}<0.001$ in all cases; fig $1 \mathrm{~A})$. In contrast, mean NO release was similar whether HUVECs, NIH 3 T3 fibroblasts or HEp-2 cells had been incubated with sera from SSc patients or with normal sera (fig 1B).

As ROS can modulate cell proliferation, we tested the effects of SSc sera on the proliferation of NIH 3T3 cells and human fibroblasts and HUVECs, and HEp-2 cells as control. SSc sera exerted a higher proliferative effect on NIH $3 \mathrm{~T} 3$ fibroblasts (fig lC) and on human fibroblasts (fig lD) than normal sera ( $\mathrm{p}=0.03$ and $\mathrm{p}=0.001$, respectively) and exerted an antiproliferative effect on HUVECs when compared with normal sera $(p<0.001)$. No difference between SSc sera and control sera was observed on HEp-2 cells (fig lC). A strong correlation was observed between the proliferative effect exerted by SSc sera on normal human fibroblasts and on NIH 3T3 cells $(\mathrm{r}=0.85 ; \mathrm{p}<0.0001)$.

$\mathrm{H}_{2} \mathrm{O}_{2}$ production by NIH $3 \mathrm{~T} 3$ fibroblasts was correlated with SSc serum-induced proliferation $(r=0.31, p=0.02)$. The antiproliferative effect observed on HUVECs was also correlated with the amounts of $\mathrm{H}_{2} \mathrm{O}_{2}$ produced by these cells $(\mathrm{r}=-0.30$, $\mathrm{p}=0.03)$.

\section{Correlations between clinical involvement of the disease and serum-induced ROS production and cellular proliferation}

Sera from the 11 patients with a RS induced higher levels of $\mathrm{H}_{2} \mathrm{O}_{2}$ than sera from the 28 SSc patients with no RS and no vascular abnormality and from healthy subjects $(p=0.02$ and $\mathrm{p}<0.0001$; fig 2A). Conversely, sera from these 11 patients did not induce higher release of NO compared with sera from the two other groups (fig 2B). These 11 sera exerted no higher proliferative effect on HUVECs than sera from patients with digital ischaemia or vascular PAH, or from SSc patients with no RS and no vascular abnormality (fig $2 \mathrm{C}$ and data not shown). In contrast, these 11 sera exerted a significantly higher proliferative effect on NIH $3 \mathrm{~T} 3$ fibroblasts compared with sera from patients with no RS and no vascular abnormality, from patients with digital ischaemia, with vascular $\mathrm{PAH}$ and from healthy subjects $(\mathrm{p}=0.04 ; \mathrm{p}=0.04 ; \mathrm{p}=0.02 ; \mathrm{p}=0.008$; fig $2 \mathrm{D}$ and data not shown).

Sera from the 18 patients with vascular abnormality (11 patients with digital ischaemia, 5 with $\mathrm{PAH}$ and 1 with both involvements) induced a higher release of NO by HUVECs than sera from the 11 patients with a RS and from the 28 SSc patients with no RS and no vascular abnormality $(p=0.01$ and $\mathrm{p}=0.03$, respectively; fig $2 \mathrm{~B}$ ). These 18 sera exerted no effect on
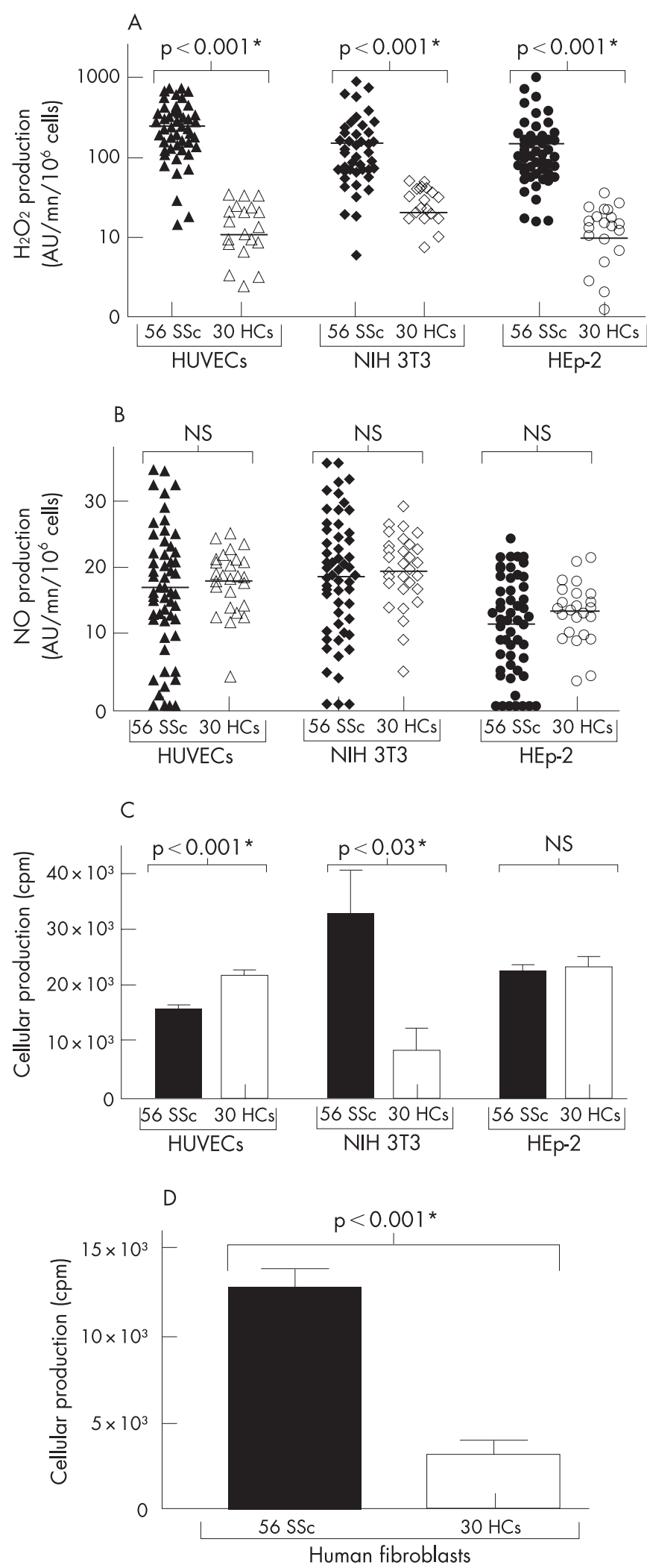

Figure 1 Effects of 56 sera from SSc patients (solid symbols) and 30 sera from healthy controls (HCs) (open symbols) on ROS generation and cell proliferation. (A) Production of hydrogen peroxide $\left(\mathrm{H}_{2} \mathrm{O}_{2}\right)$ and (B) Production of nitric oxide (NO) by human umbilical venous endothelial cells (HUVECs), NIH 3T3 fibroblasts and HEp-2 cells. (C) Cell proliferation determined by $\left[{ }^{3} \mathrm{H}\right]$ thymidine incorporation. (D) Primary normal human fibroblast proliferation. Error bars represent SEM. *Denotes statistical significance. 

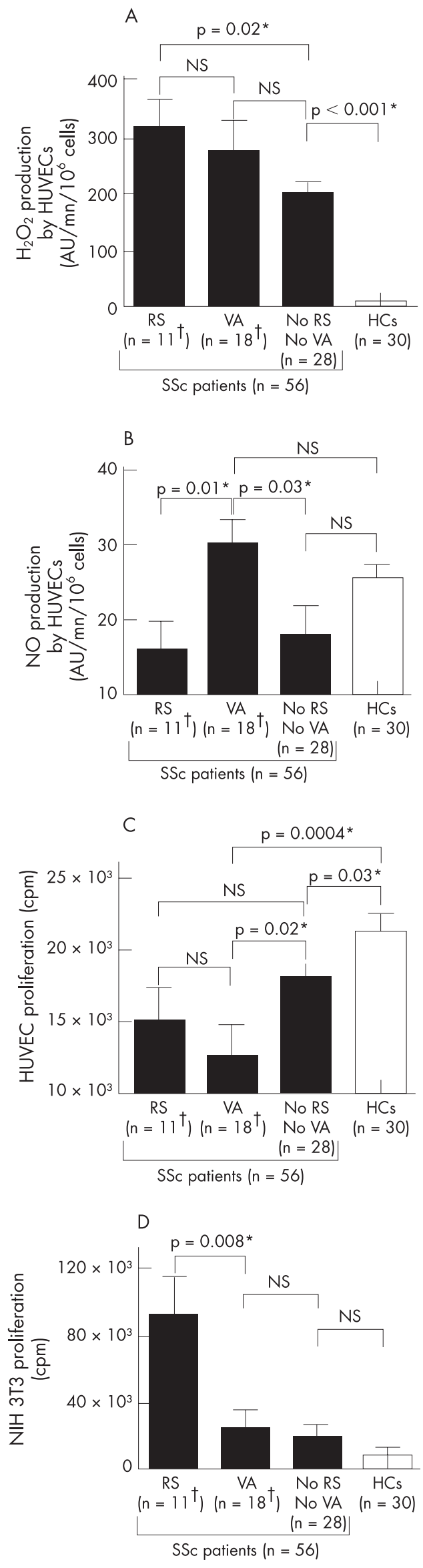

the growth of NIH $3 \mathrm{~T} 3$ fibroblasts when compared with sera from the 28 SSc patients with no RS and no vascular abnormality and with sera from healthy controls (fig 2D), but abrogated the proliferation of HUVECs more strongly than the sera from these two other groups of individuals $(p=0.02$ and $\mathrm{p}=0.0004$, respectively; fig $2 \mathrm{C}$ ). Among these 18 patients with vascular abnormality, no difference was observed between patients with digital ischaemia and those with $\mathrm{PAH}$ either in $\mathrm{H}_{2} \mathrm{O}_{2}$ and $\mathrm{NO}$ induction or in modulation of cell proliferation. Nevertheless, the sera from the 12 patients with digital ischaemia abrogated the proliferation of HUVECs more strongly than the sera from the 28 SSc patients with no RS and no vascular abnormality $(p=0.02$ and $p=0.18$, respectively; data not shown). This significant difference was not observed with sera from the six patients with PAH.

Conversely, $50 \%$ of the 12 patients with significant seruminduced fibroblast proliferation versus controls presented with a RS that was detected in only $11.4 \%$ of the other SSc patients $(p=0.007)$. Fifty-five percent of patients with significant serum-induced anti-proliferative effect on HUVECs suffered from digital ischaemia that was present in only $13 \%$ of the other SSc patients $(\mathrm{p}=0.007)$.

No difference was observed in $\mathrm{NO}$ and $\mathrm{H}_{2} \mathrm{O}_{2}$ release and on cell proliferation between patients with diffuse or limited cutaneous SSc.

\section{Serum AOPPs are responsible for ROS production and modulate fibroblast proliferation}

We then characterized the serum factors responsible for the oxidative stress. We observed no correlations between anticentromere, anti-topoisomerase l (table 1), anti-endothelial cell (24\% SSc sera) or anti-fibroblast antibodies (28\% SSc sera), and $\mathrm{H}_{2} \mathrm{O}_{2}$ or NO production by endothelial cells or fibroblasts $(\mathrm{p} \geqslant 0.13$ in each case). In addition, the depletion of serum IgG by protein $G$ (assessed by nephelometric assay) affected neither serum-induced ROS production nor fibroblast proliferation (data not shown).

The serum concentration of AOPPs was higher in SSC patients than in healthy controls $(p=0.02$; fig $3 \mathrm{~A})$ and was correlated with the induction of $\mathrm{H}_{2} \mathrm{O}_{2}$ production by HUVECs $(\mathrm{r}=0.46, \mathrm{p}<0.001)$, NIH $3 \mathrm{~T} 3$ cells $(\mathrm{r}=0.35, \mathrm{p}=0.01)$ and HEp2 cells $(r=0.31, p=0.02)$. HOCl-induced AOPP activated endothelial cells and, to a lesser extent, fibroblasts, whereas $\mathrm{ONOO}^{-}$-induced AOPP activated endothelial cells only. HOClAOPP induced more $\mathrm{H}_{2} \mathrm{O}_{2}$ than $\mathrm{NO}$, whereas $\mathrm{ONOO}^{-}$-AOPP mainly induced NO (fig $3 \mathrm{~B}$ and $3 \mathrm{C}$ ). Furthermore, a dosedependent proliferative response was observed with $\mathrm{HOCl}-$ AOPP and, to a lesser extent, with $\mathrm{ONOO}^{-}$-AOPP (data not shown).

\section{Disease-modifying agents modulate ROS generation and cellular proliferation induced by SSc sera}

The ROS production and the fibroblast proliferation induced by the sera from seven patients $(12.5 \%)$ who received immunosuppressive therapy at the time of serum collection was similar to those induced by SSc sera from non-treated patients.

Figure 2 ROS production and cell proliferation induced by sera from SSc patients according to their clinical pattern. A total of 11 patients had a restrictive syndrome (RS); 18 had vascular abnormalities (VAs); 28 had none of these complications; 30 sera were collected from healthy controls (HCs). (A) Serum-induced production of hydrogen peroxide $\left(\mathrm{H}_{2} \mathrm{O}_{2}\right)$ by human umbilical venous endothelial cells (HUVECs). (B) Serum-induced production of nitric oxide (NO) production by HUVECs. (C) Serum-induced proliferation of HUVECs. (D) Serum-induced proliferation of NIH 3T3 fibroblasts. Error bars represent SEM. *Denotes statistical significance. tone patient had both a RS and VAs. 

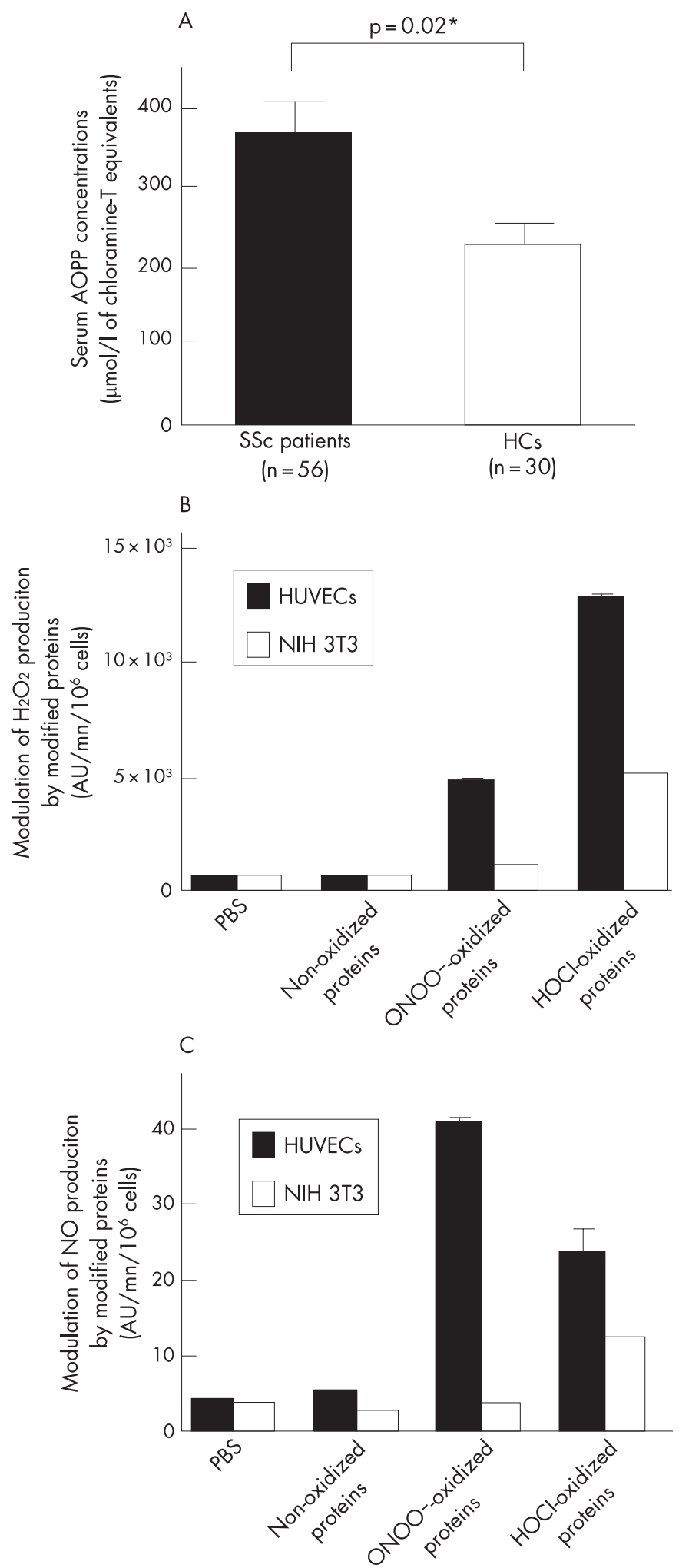

Figure 3 Role of AOPPs in serum-induced ROS production. (A) Serum AOPP concentration in $56 \mathrm{SSc}$ patients and in 30 healthy controls (HCs). Data are means \pm SEM. (B) Production of hydrogen peroxide $\left(\mathrm{H}_{2} \mathrm{O}_{2}\right)$ induced by HOCl-AOPP, peroxynitrites-AOPP or non-oxidized proteins by endothelial cells and fibroblasts. (C) Production of nitric oxide (NO) induced by $\mathrm{HOCl}-\mathrm{AOPP}$ or peroxynitrites-AOPP or non-oxidized proteins in endothelial cells and fibroblasts. Data are means \pm SEM. *Denotes statistical significance.

However, the sera from patients with immunosuppression abolished NO release by HUVECs (mean NO release: $10.14 \pm 2.3$ vs $17.4 \pm 1.3 ; \mathrm{p}=0.049)$. Seven other patients $(12.5 \%)$ received
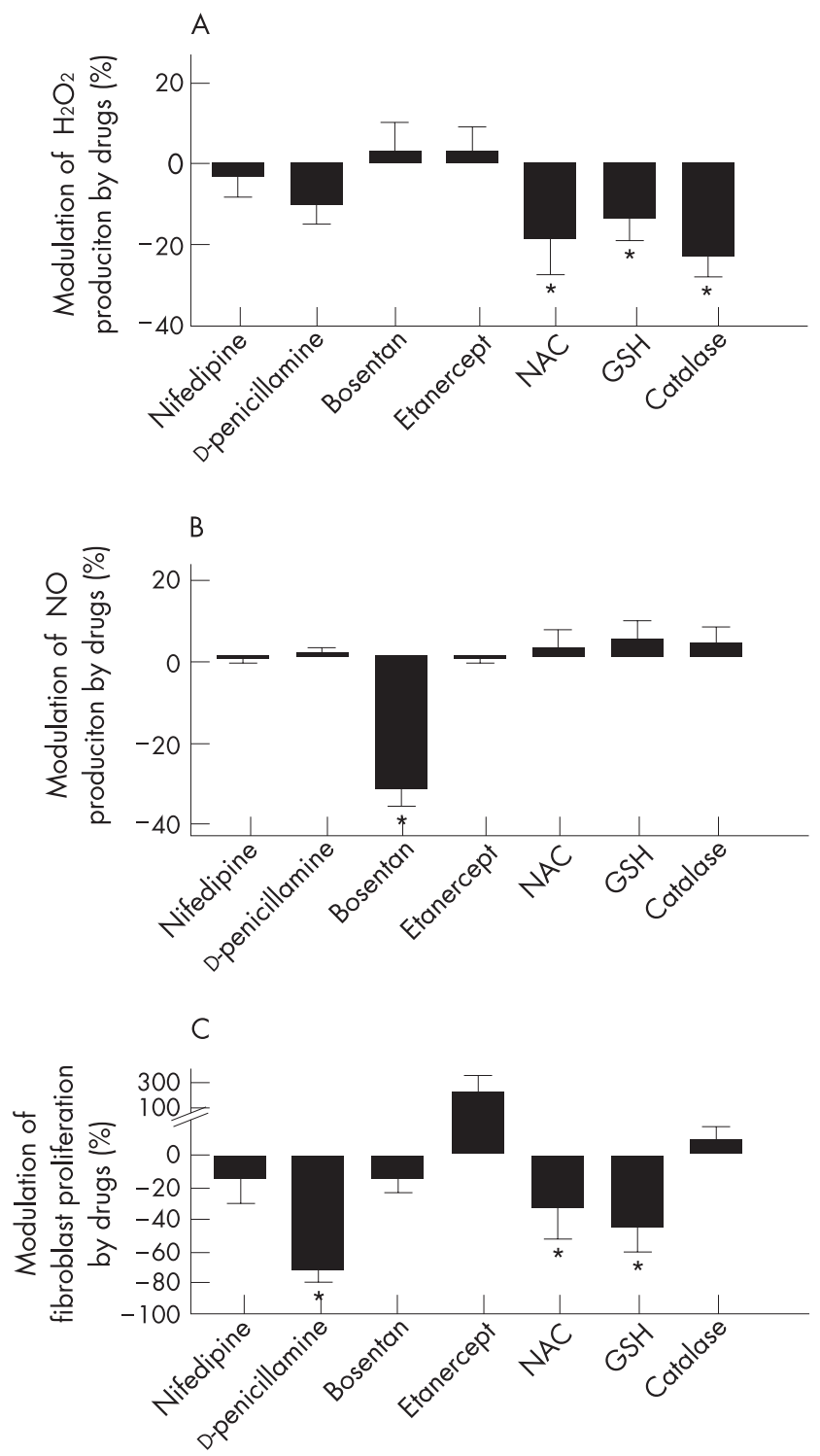

Figure 4 Modulation of serum-induced ROS generation and cell proliferation by antioxidative drugs. (A) Modulation of hydrogen peroxide $\left(\mathrm{H}_{2} \mathrm{O}_{2}\right)$ production by human umbilical venous endothelial cells (HUVECs). (B) Modulation of nitric oxide (NO) production by HUVECs. (C) Modulation of NIH 3T3 fibroblast proliferation. In A, B and C, HUVECs and fibroblasts were incubated with SSc sera and one of the following molecules: $10 \mu \mathrm{M}$ nifedipine, $50 \mu \mathrm{M}$ D-penicillamine, $50 \mu \mathrm{M}$ bosentan, $10 \mu \mathrm{g}$ etanercept, $1600 \mu \mathrm{M}$ NAC, $400 \mu \mathrm{M}$ reduced GSH or $10 \mathrm{U}$ PEG-catalase. Results are expressed as percentages of ROS production or fibroblast proliferation versus untreated cells (100\%). Error bars represent SEM.

angiotensin-converting enzyme inhibitors. Their sera exerted the same effects as sera from SSc patients who did not receive this type of drug.

In vitro, no significant effect on $\mathrm{H}_{2} \mathrm{O}_{2}$ generation by HUVECs was observed in the presence of nifedipine, D-penicillamine or etanercept. Catalase, NAC and GSH decreased $\mathrm{H}_{2} \mathrm{O}_{2}$ levels by $23.4 \%(p=0.006), 24.9 \%(p=0.048)$ and $14.2 \%(p=0.05)$, respectively (fig 4A). GSH increased HUVEC proliferation by $5 \%$ $(p=0.29)$ and NAC by $22.2 \%(p=0.07)$, and catalase significantly improved the proliferation of HUVECs by $53 \%$ $(\mathrm{p}=0.047)$ (data not shown).

Bosentan inhibited NO release by $32.7 \%(\mathrm{p}<0.001)$ on HUVECs, whereas other molecules did not (fig 4B). GSH and catalase decreased SSc serum-induced production of $\mathrm{H}_{2} \mathrm{O}_{2}$ by NIH 3 T3 cells by $19.8 \%(p=0.048)$ and by $27.8 \%(p=0.044)$, 


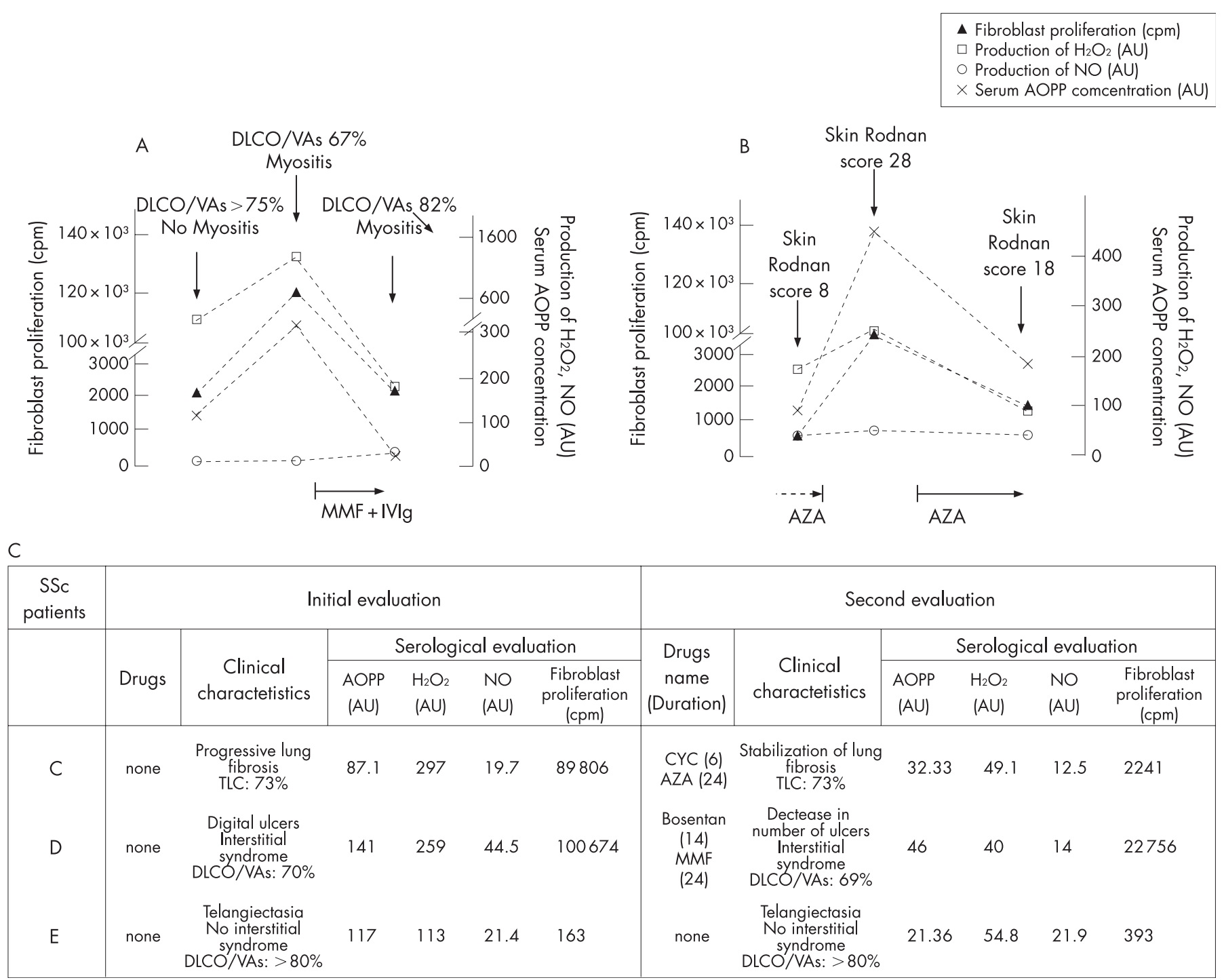

Figure 5 Longitudinal study of ex vivo serum-induced ROS production by HUVECs, proliferation of NIH 3 T3 fibroblast proliferation and serum AOPP concentrations in five patients. (A) Patient A had progressive restrictive syndrome (RS) with decreased XXX/vascular abnormalities (DLCO/VAs) and biopsyproven inflammatory myositis. He received mycophenolate mofetyl and intravenous immunoglobulins. Test values from three successive sera obtained every 6 months are presented. (B) Patient B had diffuse systemic sclerosis (SSc) with progressive deterioration of the Rodnan's score. Test values from three successive sera are presented. Azathioprin was given at the time of the collection of the first serum, then suspended and resumed at the time of collection of the third serum sample. (C) Patient $C$ had a RS related to lung fibrosis. (D) Patient D had RS and digital ulcers. Both patients $C$ and D had been receiving immunosuppressive drugs at the time of the second serum collection. Patient E had SSc without complication and received no immunosuppressant. AZA, azathioprin; CYC, cyclophosphamide; DLCO, carbon monoxide diffusing capacity; IVlg, intravenous immunoglobulins; MMF, mycophenolate mofetyl; TLC, total lung capacity.

respectively, whereas NAC did not (data not shown). GSH, Dpenicillamine and $5 \mathrm{FU}$ inhibited fibroblast proliferation by $45.15 \%(p=0.047), 71.8 \%(p<0.001)$ and $78.4 \%(p<0.001)$, respectively, whereas NAC alone did not $(p=0.15)$ (fig $4 C)$. However, NAC potentiated the anti-proliferative activity of 5FU on fibroblasts by $10 \%(p=0.02)$. Nifedipine, bosentan, etanercept and catalase had no or little effect on fibroblast proliferation (fig 4C).

\section{Longitudinal study of in vitro ROS production by HUVECs and NIH 3 T3 fibroblast proliferation}

In four patients (patients A, B, C and D), clinical involvement worsened and immunosuppressive $\operatorname{drug}(\mathrm{s})$ was (were) given (fig 5A, 5B and 5C). AOPP concentrations and serum-induced $\mathrm{H}_{2} \mathrm{O}_{2}$ production decreased when the clinical status stabilised or improved. In patient $\mathrm{E}$, no visceral involvement was detected in the course of the disease and serum properties were not modified when assayed longitudinally (fig 5C).

\section{DISCUSSION}

This report highlights the involvement of the oxidative stress in SSc and describes new serum markers in order to assess the activity of the disease and predict the response to treatment.

A common feature of the SSc sera tested in this study is their ability to induce the production of $\mathrm{H}_{2} \mathrm{O}_{2}$, particularly by endothelial cells. As ROS can modulate cell activation and proliferation, ${ }^{18}{ }^{18}$ and as fibroblasts and endothelial cells are selectively targeted in SSc, we tested the effects of SSc sera on the proliferation of murine and human fibroblasts and HUVECs. SSc sera exert a cell-specific proliferative effect, as the same sera that stimulate fibroblasts to proliferate, inhibit HUVEC proliferation and have no effect on HEp-2 cells. The difference observed between fibroblasts and endothelial cells could be related to the level of ROS produced, as a reverse correlation between the rate of proliferation and that of $\mathrm{H}_{2} \mathrm{O}_{2}$ production is observed in both types of cell. The high levels of $\mathrm{H}_{2} \mathrm{O}_{2}$ generated in endothelial cells probably reaches the 
threshold of toxicity and inhibits cell proliferation, whereas the proliferation of fibroblasts from SSc patients is directly correlated with intrinsic production of $\mathrm{H}_{2} \mathrm{O}_{2}$ as previously shown. ${ }^{6}{ }^{19}$

We then observed that the sera from patients with a RS induce a higher production of $\mathrm{H}_{2} \mathrm{O}_{2}$ and a higher fibroblast proliferation than sera from other SSc patients. Those data are in agreement with the previous finding that the synthesis of collagen by fibroblasts from SSc patients is correlated with the oxidative stress. ${ }^{6}{ }^{19}$

On the other hand, serum-induced NO release is associated with digital ischaemia or $\mathrm{PAH}$, although beneficial vasodilating effects could have been expected from a high rate of NO production. ${ }^{20-24}$ The deleterious effect of NO might be related to its combination with other ROS to form highly toxic peroxynitrites, resulting in cell injuries and cell death. ${ }^{25} 26$

We next characterized the serum factors responsible for the oxidative stress. In our experience, the prevalence of autoantibodies to endothelial cells and fibroblasts is that found usually in SSc, ${ }^{27-30}$ but those antibodies are not correlated with serum-induced ROS production or cell proliferation. Therefore, we turned to AOPPs, the concentration of which has been found to be elevated in SSc sera by us and others ${ }^{81}$ and that can trigger a respiratory burst in monocytes. ${ }^{16}$ In our experience, AOPPs activate endothelial cells and, to a lesser extent, fibroblasts to generate ROS. Furthermore, AOPPs generated by different oxidation patterns lead to the production of either $\mathrm{NO}$ or $\mathrm{H}_{2} \mathrm{O}_{2}$, suggesting that AOPPs may be involved in the generation of different types of ROS in SSc patients. However, the role of autoantibodies cannot be totally ruled out. For instance, anti-PDGF receptor antibodies ${ }^{32}$, and possibly environmental factors, ${ }^{43-35}$ could initiate a secondary selfmaintained process ${ }^{3}$ that is linked to the production of AOPPs and ROS that perpetuate the disease.

We finally investigated whether drugs used in SSc and antioxidant molecules can modulate the pro-activating effects of SSc sera. NAC and GSH decrease the generation of $\mathrm{H}_{2} \mathrm{O}_{2}$ by HUVECs and the proliferation of fibroblasts following incubation with the majority of SSc sera. This is in accordance with the observation that NAC can decrease ROS production in SSC fibroblasts, inhibit their proliferation and collagen synthesis, ${ }^{6}$ and abrogate $\mathrm{ONOO}^{-}$synthesis by activated lung macrophages from SSc patients in vitro. ${ }^{36}$ In addition, we observed that NAC potentiates the anti-proliferative effect of 5FU, which is in agreement with the beneficial effect of NAC in association with immunosuppressive therapies observed in patients with lung idiopathic interstitial fibrosis. ${ }^{37}$

Bosentan, an antagonist of endothelin A and B receptors that exerts beneficial effects in SSc patients with pulmonary arterial hypertension, ${ }^{38-40}$ abrogates NO overproduction by HUVECs stimulated by sera from patients with vascular complications. Consequently, this drug could be preferentially used in SSC patients whose sera trigger NO release, prior to the development of severe vascular complications. Prospective therapeutic trials have to be performed in SSc patients to confirm these results.

In conclusion, our data underline a pivotal role of serum factors, such as ROS and AOPPs, in the pathogenesis of the different patterns observed in SSc. These serum markers could help in assessing the activity of SSc and selecting the most appropriate treatments according to the fibrotic or vascular pattern.

\section{ACKNOWLEDGEMENTS}

Amélie Servettaz received a grant from Actelion and the Association des Sclérodermiques de France. Philippe Guilpain received a grant from the Fondation pour la Recherche Médicale (FRM).

\section{Authors' affiliations}

A Servettaz, P Guilpain, C Chéreau, L Guillevin, L Mouthon, Université

Paris-Descartes, Faculté de Médecine, IFR Alfred Jost, Paris, France, and Service de Médecine Interne, Centre National de Référence SclérodermieVascularites, AP-HP, Hôpital Cochin, Paris, France

C Goulvestre, C Hercend, C Nicco, B Weill, F Batteux, Université ParisDescartes, Faculté de Médecine, Laboratoire d'immunologie, IFR Alfred Jost, Paris, France

Competing interests: None declared

\section{REFERENCES}

1 Clements PJ. Systemic sclerosis (scleroderma) and related disorders: clinical aspects. Baillieres Best Pract Res Clin Rheumatol 2000;14:1-16.

2 Tamby MC, Chanseaud Y, Guillevin L, Mouthon L. New insights into the pathogenesis of systemic sclerosis. Autoimmunity Rev 2003;2:152-7.

3 Herrick AL, Worthington A. Genetic epidemiology: Systemic sclerosis. Arthritis Res 2002:4:165-8.

4 Lunardi C, Bason C, Navone R, Millo E, Damonte G, Corrocher R, et al. Systemic sclerosis immunoglobulin $G$ autoantibodies bind the human cytomegalovirus late protein UL94 and induce apoptosis in human endothelial cells. Nat Med 2000;6:1183-6.

5 Nietert PJ, Silver RM. Systemic sclerosis: environmental and occupational risk factors. Curr Opin Rheumatol 2000;12:520-6.

6 Sambo P, Baroni SS, Luchetti M, Paroncini P, Dusi S, Orlandini G, et al. Oxidative stress in scleroderma: maintenance of scleroderma fibroblast phenotype by the constitutive up-regulation of reactive oxygen species generation through the NADPH oxidase complex pathway. Arthritis Rheum 2001;44:2653-64.

7 Ogawa F, Shimizu K, Muroi E, Hara T, Hasegawa M, Takehara K, et al. Serum levels of 8-isoprostane, a marker of oxidative stress, are elevated in patients with systemic sclerosis. Rheumatology 2006:45:815-8.

8 Allanore Y, Borderie D, Lemarechal H, Ekindjian OG, Kahan A. Acute and sustained effects of dihydropyridine-type calcium channel antagonists on oxidative stress in systemic sclerosis. Am J Med 2004; 1 16:595-600.

9 Herrick AL, Rieley F, Schofield D, Hollis S, Braganza JM, Jayson MIV. Micronutrient antioxidant status in patients with primary Raynaud's phenomenon and systemic sclerosis. J Rheumatol 1994;21:1477-83.

10 Sambo P, Jannino L, Candela M, Salvi A, Donini M, Dusi S, et al. Monocytes of patients with systemic sclerosis (scleroderma) spontaneously release in vitro increased amounts of superoxide anion. J Invest Dermatol 1999; 1 12:78-84.

11 Masi AT, Rodnan GP, Medsger TA, Altman RD, D'Angelo WA, Fries JF. Preliminary criteria for the classification of systemic sclerosis (scleroderma) Subcommittee for scleroderma criteria of the American Rheumatism Association Diagnostic and Therapeutic Criteria Committee. Arthritis Rheum 1980;23:581-90.

12 LeRoy EC, Black C, Fleischmajer R, Jablonska S, Krieg T, Medsger TAJ, et al. Scleroderma (systemic sclerosis): classification, subsets and pathogenesis. J Rheumatol 1988;15:202-5.

13 LeRoy EC, Medsger TAJ. Criteria for the classification of early systemic sclerosis J Rheumatol 2001;28:1573-6.

14 Chanseaud Y, Pena-Lefebvre PG, Guilpain P, Mahr A, Tamby MC, Uzan M, et al. $\lg M$ and $\lg G$ autoantibodies from microscopic polyangeitis patients but not those with other small- and medium-sized vessel vasculitides recognize multiple endothelial cell antigens. Clin Immunol 2003;109:165-78.

15 Tamby MC, Humbert M, Guilpain P, Servettaz A, Dupin N, Christner JJ, et al. Antibodies to fibroblasts in idiopathic and scleroderma-associated pulmonary hypertension. Eur Respir J 2006;28:799-807.

16 Witko-Sarsat V, Friedlander M, Capeillere-Blandin C, Nguyen-Khoa T, Nguyen AT, Zingraff J, et al. Advanced oxidation protein products as a novel marker of oxidative stress in uremia. Kidney Int 1996;49:1304-13.

17 Laurent A, Nicco C, Chereau C, Goulvestre C, Alexandre J, Alves A, et al. Controlling tumor growth by modulating endogenous production of reactive oxygen species. Cancer Res 2005;65:948-56.

18 Nicco C, Laurent A, Chereau C, Weill B, Batteux F. Differential modulation of normal and tumor cell proliferation by reactive oxygen species. Biomed Pharmacother 2005;59:169-74.

19 Svegliati S, Cancello R, Sambo P, Luchetti M, Paroncini P, Orlandini G, et al. Platelet-derived growth factor and reactive oxygen species (ROS) regulate Ras protein levels in primary human fibroblasts via ERK1/2. J Biol Chem 2005;280:36474-82.

20 Herrick AL, Matucci Cerinic M. The emerging problem of oxidative stress and the role of antioxidants in systemic sclerosis. Clin Exp Rheumatol 2001;19:4-8.

21 Ignarro LJ. Endothelium-derived nitric oxide: actions and properties. Faseb J 1989:3:31-6.

22 Andersen GN, Caidahl K, Kazzam E, Petersson AS, Waldenstrom A, MinchevaNilsson L, et al. Correlation between increased nitric oxide production and markers of endothelial activation in systemic sclerosis: findings with the soluble adhesion molecules E-selectin, intercellular adhesion molecule 1, and vascular cell adhesion molecule 1. Arthritis Rheum 2000;43:1085-93.

23 Moodley YP, Lalloo UG. Exhaled nitric oxide is elevated in patients with progressive systemic sclerosis without interstitial lung disease. Chest 2001;119:1449-54.

24 Takagi K, Kawaguchi Y, Hara M, Sugiura T, Harigai M, Kamatani N. Serum nitric oxide (NO) levels in systemic sclerosis patients: correlation between NO levels and clinical features. Clin Exp Immunol 2003;134:538-44. 
25 Cotton SA, Herrick AL, Jayson MI, Freemont AJ. Endothelial expression of nitric oxide synthases and nitrotyrosine in systemic sclerosis skin. J Pathol 1999;189:273-8

26 Matucci-Cerinic $M$, Kahaleh MB. Beauty and the beast. The nitric oxide paradox in systemic sclerosis. Rheumatology 2002:41:843-7.

27 Ihn H, Sato S, Fujimoto M, Igarashi A, Yazawa N, Kubo M, et al. Characterization of autoantibodies to endothelial cells in systemic sclerosis (SSc): association with pulmonary fibrosis. Clin Exp Immunol 2000;1 19:203-9.

28 Salojin KV, Le Tonqueze M, Saraux A, Nassonov EL, Dueymes M, Piette JC, et al. Antiendothelial cell antibodies: useful markers of systemic sclerosis. Am J Med 1997; 102:178-85.

29 Servettaz A, Tamby MC, Guilpain P, Reinbolt J, Garcia De La Pena-Lefebvre P, Allanore $Y$, et al. Anti-endothelial cell antibodies from patients with limited cutaneous systemic sclerosis bind to centromeric protein B (CENP-B). Clin Immunol 2006;120:212-9.

30 Garcia De La Pena-Lefebvre P, Chanseaud Y, Tamby MC, Reinbolt J, Batteux F, Allanore $Y$, et al. IgG reactivity with a 100-kDa tissue and endothelial cell antigen identified as topoisomerase 1 distinguishes between limited and diffuse systemic sclerosis patients. Clin Immunol 2004;111:241-51.

31 Solans R, Motta C, Sola R, La Ville AE, Lima J, Simeon P, et al. Abnormalities of erythrocyte membrane fluidity, lipid composition, and lipid peroxidation in systemic sclerosis. Arthritis Rheum 2000:43:894-900

32 Svegliati Baroni S, Santillo M, Bevilacqua F, Luchetti M, Spadoni T, Mancini M, et al. Stimulatory autoantibodies to the PDGF receptor in systemic sclerosis. N Engl J Med 2006;354:2667-76.
33 Lunardi C, Dolcino M, Peterlana D, Bason C, Navone R, Tamassia N, et al. Antibodies against human cytomegalovirus in the pathogenesis of systemic sclerosis: a gene array approach. PLoS Med 2006;3:94-108.

34 Diot E, Lesire V, Guilmot JL, Metzger MD, Pilore R, Rogier S, et al. Systemic sclerosis and occupational risk factors: a case-control study. Occup Environ Med 2002;59:545-9.

35 Fubini B, Hubbard A. Reactive oxygen species (ROS) and reactive nitrogen species (RNS) generation by silica in inflammation and fibrosis. Free Radic Biol Med 2003:34:1507-16.

36 Failli P, Palmieri L, D’Alfonso C, Giovannelli L, Generini S, Rosso AD, et al. Effect of $\mathrm{N}$-acetyl-L-cysteine on peroxynitrite and superoxide anion production of lung alveolar macrophages in systemic sclerosis. Nitric Oxide 2002; 7:277-82.

37 Demedts M, Behr J, Buhl R, Costabel U, Dekhuijzen R, Jansen HM, et al. Highdose acetylcysteine in idiopathic pulmonary fibrosis. N Engl J Med 2005;353:2229-42.

38 Rubin LJ, Badesch DB, Barst RJ, Galie N, Black CM, Keogh A, et al. Bosentan therapy for pulmonary arterial hypertension. N Engl J Med 2002;346:896-903.

39 Channick RN, Simonneau G, Sitbon O, Robbins IM, Frost A, Tapson VF, et al. Effects of the dual endothelin-receptor antagonist bosentan in patients with pulmonary hypertension: a randomised placebo-controlled study. Lancet $2001 ; 6: 1119-23$.

40 Humbert M, Cabane J. Successful treatment of systemic sclerosis digital ulcers and pulmonary arterial hypertension with endothelin receptor antagonist bosentan. Rheumatology 2003;42:191-3.

\section{Access the latest content chosen by our Editors}

BMJ Journals editors select an article from each issue to be made free online immediately on publication. Other material is free after 12 months to non-subscribers. Access the Editor's Choice from the home page-or expand your horizons and see what the other BMJ Journals editors have chosen by following the links on any BMJ Journal home page. 